УДК 314.1

$10.17213 / 2075-2067-2021-2-7-20$

\title{
УСИЛЕНИЕ ДЕПОПУЛЯЦИИ В РОССИИ \\ В КОНТЕКСТЕ ПАНДЕМИИ COVID-19: РЕГИОНАЛЬНЫЕ ОСОБЕННОСТИ ${ }^{1}$
}

\author{
(C) 2021 г. С. В. Рязанцев, А. Е. Иванова, В. Н. Архангельский \\ Институт демографических исследований \\ Федерального научно-исследовательского социологического центра РАН, \\ 2. Москва, Россия
}

Цель исследования. В статье рассматривается демографическая ситуачия в России в 2020 году в контексте второй волны депопуляции, усугубленной пандемией COVID-19.

Методы исследования включают анализ и расчеты данных текущего учета рождаемости, смертности и миграции на основе сведений Федеральной службы государственной статистики, органов ЗАГС города Москвы, а также Главного управления по вопросам миграчии МВД России.

Результаты исследования. Пандемия COVID-19 cmала новым фактором депопулящии в России, прежде всего, из-за роста смертности и снижения миграционной мобильности населения. Новая волна депопулячиии в России происходит под двойным давлением: с одной стороны, это традииионные факторы изменения демографических тенденций, а с другой - экстремальное действие фактора пандемии COVID-19. В результате избыточной смертности в 2020 году на фоне пандемии прервался длительный позитивный тренд роста продолжительности жизни в России, который сохранялся даже в кризисные периоды 2008-2009 годов и после 2014 года. Основной вклад в снижение общих показателей рождаемости вносят изменения в половозрастной структуре населения - в активный репродуктивный возраст входят малочисленные поколения родивиихся в 1990-е годы. Динамика показателей рождаемости существенно различается по очередности рождения, имеет влияние структурного фактора. Благоприятная динамика численности женщин репродуктивного возраста имеет место в возрастах за 35 лет (число родившихся в России возрастало до 1987 года), в которых доля третьих и последующих рождений существенно выше, чем у более молодых женщин. В современных условиях России надо искать выход в усилении вклада миграционной компоненты в демографическую динамику. Прежде всего, необходимо увеличение реэмиграции русских из стран бывщего СССР.

Перспективы исследования. Вторая волна депопулящии требует разработки новых мер демографической и миграчионной политики, которые помогут компенсировать сокращчение численности населения в России. Для выхода из второй волны депопуляции требуется научно обоснованная национальная демографическая программа.

Ключевые слова: демографическая ситуация; депопулячия; демографическая политика; пандемия COVID-19; рождаемость; смертность; миграџия; численность населения.

1 Исследование выполнено при финансовой поддержке РФФИ и Тюменской области в рамках научного проекта № 20-411-720005. 


\title{
INCREASING DEPOPULATION IN RUSSIA \\ IN THE CONTEXT OF THE COVID-19 PANDEMIC: REGIONAL FEATURES
}

\author{
(C) 2021 S. V. Ryazantsev, A. E. Ivanova, V. N. Arkhangelsky
}

\section{Institute of Demographic Research of the Federal Research Sociological Center of the Russian Academy of Sciences, Moscow, Russia}

The purpose of the study. The article examines the demographic situation in Russia in 2020 in the context of the second wave of depopulation, aggravated by the COVID-19 pandemic.

The research methods include the analysis and calculation of data on the current registration of births, deaths and migration on the basis of data from the Federal State Statistics Service, the Civil Registry Office of the City of Moscow, as well as the Main Department for Migration of the Ministry of Internal Affairs of Russia.

The results of the study. The COVID-19 pandemic has become a new factor of depopulation in Russia, primarily due to an increase in mortality and a decrease in migration mobility of the population. The new wave of depopulation in Russia is under double pressure: on the one hand, these are traditional factors of changing demographic trends, and on the other hand, the extreme effect of the COVID-19 pandemic factor. As a result of excessive mortality in 2020, against the background of the pandemic, the long-term positive trend of life expectancy growth in Russia was interrupted, which persisted even during the crisis periods of 2008-2009 and after 2014. The main contribution to the decline in the overall birth rate is made by changes in the gender and age structure of the population - the active reproductive age includes small generations born in the 1990s. The dynamics of birth rates significantly differ in the order of birth, has the influence of a structural factor. A favorable trend in the number of women of reproductive age occurs at the age of 35 (the number of births in Russia increased until 1987), in which the proportion of third and subsequent births is significantly higher than that of younger women. In the modern conditions of Russia, it is necessary to look for a way out in strengthening the contribution of the migration component to the demographic dynamics. First of all, it is necessary to increase the re-emigration of Russians from the countries of the former USSR.

Research prospects. The second wave of depopulation requires the development of new demographic and migration policies that will help compensate for the decline in the population in Russia. To get out of the second wave of depopulation, a science based national demographic program is required.

Key words: demographic situation; depopulation; demographic policy; COVID-19 pandemic; birth rate; mortality; migration; population size.

Введение. На фоне пандемии COVID-19 демографическая ситуация в России снова ухудшилась. За 2020 год, по предварительной оценке, которую дает Росстат, численность населения страны сократилась на 510 тыс. человек. Данное сокращение является самым значительным за последнее десятилетие, которое в демографическом отношении было относительно благополучным в России. На начало 2021 года, по предваритель- ной оценке Росстат, численность населения страны составила 146,2 млн. человек. В современных условиях остро встает вопрос мониторинга демографических последствий пандемии, расчета вклада COVID-19 в усугубление депопуляции новой (второй) волны депопуляции в России.

Понятие «депопуляция» характеризует стабильное сокращение численности населения, которое в свою очередь обусловлено 
падением рождаемости из-за трансформации института семьи и изменения ценностных установок на детей. В результате в стране не обеспечивается даже простое воспроизводство населения $(2,14-2,15$ ребенка на одну женщину репродуктивного возраста). Как правило, депопуляция сопровождается сокращением численности населения. На протяжении долгого периода (с 1993 по 2008 годы) в Российской Федерации отмечались негативные демографические тенденции: сокращалась численность населения, возрастала смертность, снижалась рождаемость. При этом миграционный прирост в России был практически всегда весьма значительным, но не мог компенсировать потери естественной убыли населения в стране.

Реализация мер демографической политики, которая началась в 2006-2007 годах, помогла отчасти стабилизировать ситуацию, и Россия вышла на позитивную демографическую динамику к 2008 году, когда общий прирост населения стал нулевым и затем положительным (что обеспечивалось исключительно за счет миграции). В 2013 году естественный прирост был положительным и составлял 22,9 тыс. человек: число родившихся (1901,2 тыс. чел.) впервые за многие годы превысило число умерших (1878,3 тыс. человек), т.е. депопуляция в России была приостановлена в 2013-2015 годах. Однако в 2016 году Россия вступила в новую депопуляцию («вторую волну депопуляции») в 2016 году. Именно в этом году была отмечена естественная убыль населения в объеме 2,3 тыс. человек, в то время как в предыдущие годы отмечался естественный прирост населения. Далее «ма- ховик» естественной убыли населения стал раскручиваться: в 2017 году она была 134,4, в 2018 году - 218,4, в 2019 году - 316 тыс. человек. Нами предложен и обоснован термин «вторая волна депопуляции» как характеристика демографического развития российского общества с 2016 года [1].

Данный этап характеризуется новым витком сокращения рождаемости по причинам углубления негативных изменений возрастной структуры населения и исчерпания резервов рождаемости, обусловленных импульсом воздействием мер материнского капитала (с 2007 года), позволившим многим российским семьям реализовать отложенные рождения. Пандемия COVID-19 стала новым фактором депопуляции в России, прежде всего, из-за роста смертности и снижения миграционной мобильности населения. Новая волна депопуляции в России происходит под двойным давлением: с одной стороны, это традиционные факторы изменения демографических тенденций, а с другой - экстремальное действие фактора пандемии COVID-19.

Смертность и продолжительность жизни. В 2020 году число умерших превысило 2,1 млн. человек, т.е. показатель вернулся к уровню 1993 года. Избыточная смертность в России в 2020 году составила около 324 тыс. человек (на 18\% больше, чем в 2019 году). Более трети этих потерь связаны с короновирусной инфекцией прямо или косвенно. Официальная смертность от COVID-19 в России за время пандемии составила 116 тыс. человек (табл. 1).

Таблица 1

Показатели демографического развития России в 2016-2020 годы, тыс. человек ${ }^{2}$

\begin{tabular}{|l|c|c|c|c|c|}
\hline & 2016 г. & 2017 г. & 2018 г. & 2019 г. & 2020 г. \\
\hline Число родившихся & 1888,7 & 1690,3 & 1604,3 & 1481,1 & 1435,7 \\
\hline Число умерших & 1891 & 1826,1 & 1828,9 & 1798,3 & 2124,5 \\
\hline Естественная убыль & $-2,3$ & $-135,8$ & $-224,6$ & $-317,2$ & $-688,7$ \\
\hline Миграционный прирост & 261,9 & 211,8 & 124,8 & 285,1 & 106,4 \\
\hline Общий прирост населения & 259,6 & 76 & $-99,7$ & $-32,1$ & $-582,3$ \\
\hline Численность населения на начало года & 146545 & 146804 & 146880 & 146794 & 146745 \\
\hline
\end{tabular}

2 Источник: данные Федеральной службы государственной статистики. 
Таблица 2

Региональное распределение избыточной смертности в России в 2020 году по сравнению с 2019 годом и потерь, обусловленных COVID-19, в апреле-декабре 2020 года

\begin{tabular}{|c|c|c|c|c|}
\hline \multirow[t]{2}{*}{ Регионы РФ } & \multicolumn{2}{|c|}{$\begin{array}{c}\text { Прирост числа } \\
\text { умерших в } 2020 \text { г. } \\
\text { в сравнении с } 2019 \text { г. }\end{array}$} & \multicolumn{2}{|c|}{$\begin{array}{c}\text { Число умерших } \\
\text { от COVID-19 }\end{array}$} \\
\hline & $\begin{array}{c}\text { Абсолютное } \\
\text { число }\end{array}$ & $\%$ & $\begin{array}{c}\text { Абсолютное } \\
\text { число }\end{array}$ & $\begin{array}{l}\text { \% к избыточ- } \\
\text { ным потерям }\end{array}$ \\
\hline Российская Федерация & 323802 & 18 & 117492 & 36,3 \\
\hline Алтайский край & 5054 & 15,4 & 1538 & 30,4 \\
\hline Амурская область & 1589 & 14,3 & 643 & 40,5 \\
\hline Архангельская область & 1716 & 11,5 & 1433 & 83,5 \\
\hline Астраханская область & 2150 & 18,8 & 877 & 40,8 \\
\hline Белгородская область & 3165 & 15,3 & 456 & 14,4 \\
\hline Брянская область & 2501 & 14,2 & 286 & 11,4 \\
\hline Владимирская область & 3309 & 15,5 & 721 & 21,8 \\
\hline Волгоградская область & 6262 & 19,1 & 1078 & 17,2 \\
\hline Вологодская область & 1484 & 9 & 738 & 49,7 \\
\hline Воронежская область & 5254 & 16 & 1828 & 34,8 \\
\hline г. Москва & 28233 & 23,3 & 21873 & 77,5 \\
\hline г. Санкт-Петербург & 13558 & 22,9 & 10863 & 80,1 \\
\hline г. Севастополь & 431 & 7,4 & 232 & 53,8 \\
\hline Еврейская АО & 219 & 9,6 & 147 & 67,1 \\
\hline Забайкальский край & 1137 & 8,6 & 703 & 61,8 \\
\hline Ивановская область & 1696 & 10,7 & 1107 & 65,3 \\
\hline Иркутская область & 4017 & 12,7 & 2235 & 55,6 \\
\hline Кабардино-Балкарская Республика & 1482 & 20,8 & 295 & 19,9 \\
\hline Калининградская область & 1303 & 10,9 & 801 & 61,5 \\
\hline Калужская область & 2509 & 17,1 & 428 & 17,1 \\
\hline Камчатский край & 503 & 14,5 & 300 & 59,6 \\
\hline Карачаево-Черкесская Республика & 729 & 17,3 & 174 & 23,9 \\
\hline Кемеровская область & 4767 & 12,5 & 996 & 20,9 \\
\hline Кировская область & 2864 & 15,8 & 720 & 25,1 \\
\hline Костромская область & 1096 & 11,7 & 364 & 33,2 \\
\hline Краснодарский край & 10966 & 15,7 & 2068 & 18,9 \\
\hline Красноярский край & 5184 & 14,7 & 2492 & 48,1 \\
\hline Курганская область & 1557 & 12,2 & 525 & 33,7 \\
\hline Курская область & 2428 & 14,6 & 436 & 18 \\
\hline Ленинградская область & 4568 & 19,5 & 300 & 6,6 \\
\hline Липецкая область & 3759 & 23 & 257 & 6,8 \\
\hline
\end{tabular}


Продолжение таблицы 2

\begin{tabular}{|c|c|c|c|c|}
\hline Магаданская область & 131 & 8,1 & 71 & 54,2 \\
\hline Московская область & 20303 & 22,2 & 12504 & 61,6 \\
\hline Мурманская область & 1463 & 17,3 & 775 & 53 \\
\hline Нижегородская область & 8149 & 17,4 & 2975 & 36,5 \\
\hline Новгородская область & 975 & 9,9 & 239 & 24,5 \\
\hline Новосибирская область & 6951 & 19,5 & 2478 & 35,6 \\
\hline Омская область & 5335 & 21,8 & 2497 & 46,8 \\
\hline Оренбургская область & 6018 & 23,5 & 1181 & 19,6 \\
\hline Орловская область & 1881 & 16,6 & 1011 & 53,7 \\
\hline Пензенская область & 4272 & 23,2 & 615 & 14,4 \\
\hline Пермский край & 5683 & 16,5 & 2344 & 41,2 \\
\hline Приморский край & 3107 & 12,1 & 987 & 31,8 \\
\hline Псковская область & 1197 & 11,3 & 168 & 14 \\
\hline Республика Адыгея & 413 & 7,3 & 141 & 34,1 \\
\hline Республика Алтай & 261 & 11,7 & 148 & 56,7 \\
\hline Республика Башкортостан & 10649 & 21,6 & 158 & 1,5 \\
\hline Республика Бурятия & 736 & 6,8 & 606 & 82,3 \\
\hline Республика Дагестан & 4930 & 34 & 1123 & 22,8 \\
\hline Республика Ингушетия & 426 & 29,1 & 109 & 25,6 \\
\hline Республика Калмыкия & 436 & 17 & 284 & 65,1 \\
\hline Республика Карелия & 1273 & 14,5 & 409 & 32,1 \\
\hline Республика Коми & 1073 & 10,8 & 708 & 66 \\
\hline Республика Крым & 3797 & 14,2 & 818 & 21,5 \\
\hline Республика Марий Эл & 1526 & 18,6 & 144 & 9,4 \\
\hline Республика Мордовия & 2397 & 22,9 & 205 & 8,6 \\
\hline Республика Саха (Якутия) & 1345 & 17,7 & 701 & 52,1 \\
\hline Республика Северная Осетия-Алания & 1141 & 15,8 & 155 & 13,6 \\
\hline Республика Татарстан & 11585 & 27,1 & 562 & 4,9 \\
\hline Республика Тыва & 306 & 11,3 & 212 & 69,3 \\
\hline Республика Хакасия & 765 & 11,5 & 490 & 64,1 \\
\hline Ростовская область & 8371 & 15 & 3332 & 39,8 \\
\hline Рязанская область & 2930 & 17,4 & 177 & 6 \\
\hline Самарская область & 10596 & 25,1 & 1268 & 12 \\
\hline Саратовская область & 6125 & 18,3 & 1009 & 16,5 \\
\hline Сахалинская область & 581 & 9,6 & 56 & 9,6 \\
\hline Свердловская область & 9814 & 17 & 4702 & 47,9 \\
\hline Смоленская область & 1675 & 11,8 & 524 & 31,3 \\
\hline Ставропольский край & 4657 & 14,8 & 1058 & 22,7 \\
\hline Тамбовская область & 2568 & 16,9 & 608 & 23,7 \\
\hline
\end{tabular}


Окончание таблицы 2

\begin{tabular}{|l|c|c|c|c|}
\hline Тверская область & 2498 & 12,1 & 1420 & 56,8 \\
\hline Томская область & 2227 & 18,5 & 395 & 17,7 \\
\hline Тульская область & 3830 & 16,4 & 1110 & 29 \\
\hline Тюменская область без АО & 2602 & 16,1 & 441 & 16,9 \\
\hline Удмуртская Республика & 3189 & 17,8 & 1419 & 44,5 \\
\hline Ульяновская область & 3537 & 20,7 & 1535 & 43,4 \\
\hline Хабаровский край & 2610 & 14,8 & 1616 & 61,9 \\
\hline Ханты-Мансийский АО & 2682 & 26,5 & 903 & 33,7 \\
\hline Челябинская область & 9258 & 20,3 & 2296 & 24,8 \\
\hline Чеченская Республика & 2831 & 44,5 & 166 & 5,9 \\
\hline Чувашская Республика (Чувашия) & 3488 & 22,9 & 777 & 22,3 \\
\hline Чукотский АО & 66 & 14,5 & 7 & 10,6 \\
\hline Ямало-Ненецкий АО & 734 & 28,8 & 402 & 54,8 \\
\hline Ярославская область & 2919 & 15,8 & 539 & 18,5 \\
\hline
\end{tabular}

В 2020 году во всех регионах России наблюдался рост числа умерших по сравнению с 2019 годом, но темпы различались. Минимальный рост числа умерших был отмечен в Бурятии, Адыгее и Севастополе, где потери выросли на 6,8\%, 7,3\%, 7,4\% соответственно, максимальный - в национальных республиках Северного Кавказа (на 29,1 \% в Ингушетии, 34\% в Дагестане, 44,5\% в Чечне) (табл. 2).

Исследование тенденций смертности во время пандемии показало несколько особенностей:

— во-первых, в методическом плане учет потерь от эпидемии должен базироваться на суммарном числе умерших от коронавируca c диагнозом COVID-19 как первоначальная и сопутствующая причина смерти;

- во-вторых, с высокой степенью вероятности имеет место недоучет потерь от COVID-19 за счет первого квартала 2020 г., особенно марта;

- в-третьих, не выявлено сколько-нибудь значимой связи избыточной смертности, обусловленной COVID-19, в российских регионах с географическими, социально-экономическими, этногенетическими факторами;

- в-четвертых, основными факторами, определившими потери регионов от COVID-19, явились комплексные профи- лактические мероприятия, скорее, социального характера (от численности населения в соотношении к возможностям служб здравоохранения в экстраординарных условиях до социально-экономических позиций региона, позволявших оперативно решать возникающие задачи).

В результате избыточной смертности в 2020 году на фоне пандемии прервался длительный позитивный тренд роста продолжительности жизни в России, который сохранялся даже в кризисные периоды 20082009 годов и после 2014 года. По предварительной оценке, ожидаемая продолжительность жизни населения России по итогам 2020 года снизилась до 71,1 года против 73,3 года в 2019 году, то есть более чем на два года.

Оперативная оценка свидетельствует, что глубина потерь продолжительности жизни будет довольно значительной, особенно для территорий с высоким приростом избыточной смертности. Наиболее показательна Москва. Оценка, по предварительным данным текущей статистики органов ЗАГС Москвы, говорит о примерном сокращении ожидаемой продолжительности жизни мужчин в столице на 1,6 года (с 74,8 лет в 2019 году до 73,2 лет в 2020 году) и на 1,4 лет - у женщин (с 81,6 до 80,2 лет соответственно). В отличие от кризисных социально-экономических периодов, 
в которые потери продолжительности жизни мужчин всегда оказываются существенно больше, пандемия вызвала практически одинаковый спад у мужчин и женщин.

Соотношение возрастных уровней смертности в 2020 и 2019 годах позволит выявить наиболее пострадавшие группы населения, в которых смертность возросла, а также оценить возрастной профиль увеличения смертности. В наибольшей степени пострадали лица пожилых и старческих возрастов, страдавшие хроническими заболеваниями, для которых присоединение инфекции существенно усилило и ускорило риск летального исхода.

Данные по Москве подтверждают эти наблюдения (рис. 1). Максимальный прирост смертности зафиксирован в возрастных группах старше 80 лет. Заметный прирост смертности среди детей 10-14 лет и молодежи 25-29 лет. Детская смертность в Москве существенно снизилась. В отношении младенческой смертности эффект связан с резким снижением доли рождений у иногородних, которая в 2019 г. превышала уже четверть всех рождений в столице. В возрастах старше года позитивно сказались карантинные меры, повлиявшие на снижение детского травматизма.

Чтобы понять, как сдвиги смертности в отдельных возрастах повлияли на измене- ние продолжительности жизни, используем метод декомпозиции (рис. 2).

Наибольший негативный вклад в потери продолжительности жизни внесла смертность в возрастной группе 70-74 года, тогда как максимальный прирост смертности пришелся на существенно более поздние возраста. Это связано с большими потерями недожитой жизни умершими в возрасте 70-74 года в сравнение с теми, кто умер в возрасте старше 85 лет. Снижение младенческой смертности дало выигрыш в продолжительности жизни в 0,15 года для мужчин и 0,11 года для женщин.

В настоящее время в случаях смерти людей с подозрением на COVID-19 производятся патологоанатомические вскрытия с детальным клинико-морфологическим анализом их результатов при использовании метода полимеразной цепной реакции для идентификации коронавируса. SARS-COV-2 может повышать вероятность смерти от других заболеваний, являясь сопутствующей инфекцией, а может просто присутствовать и не влиять на течение патологического процесса при других заболеваниях. В настоящее время в прессе идет дискуссия о полноте учета в России смертей от коронавирусной инфекции, основанная на утверждении, что доля последнего варианта инфицирования в смертности населе-

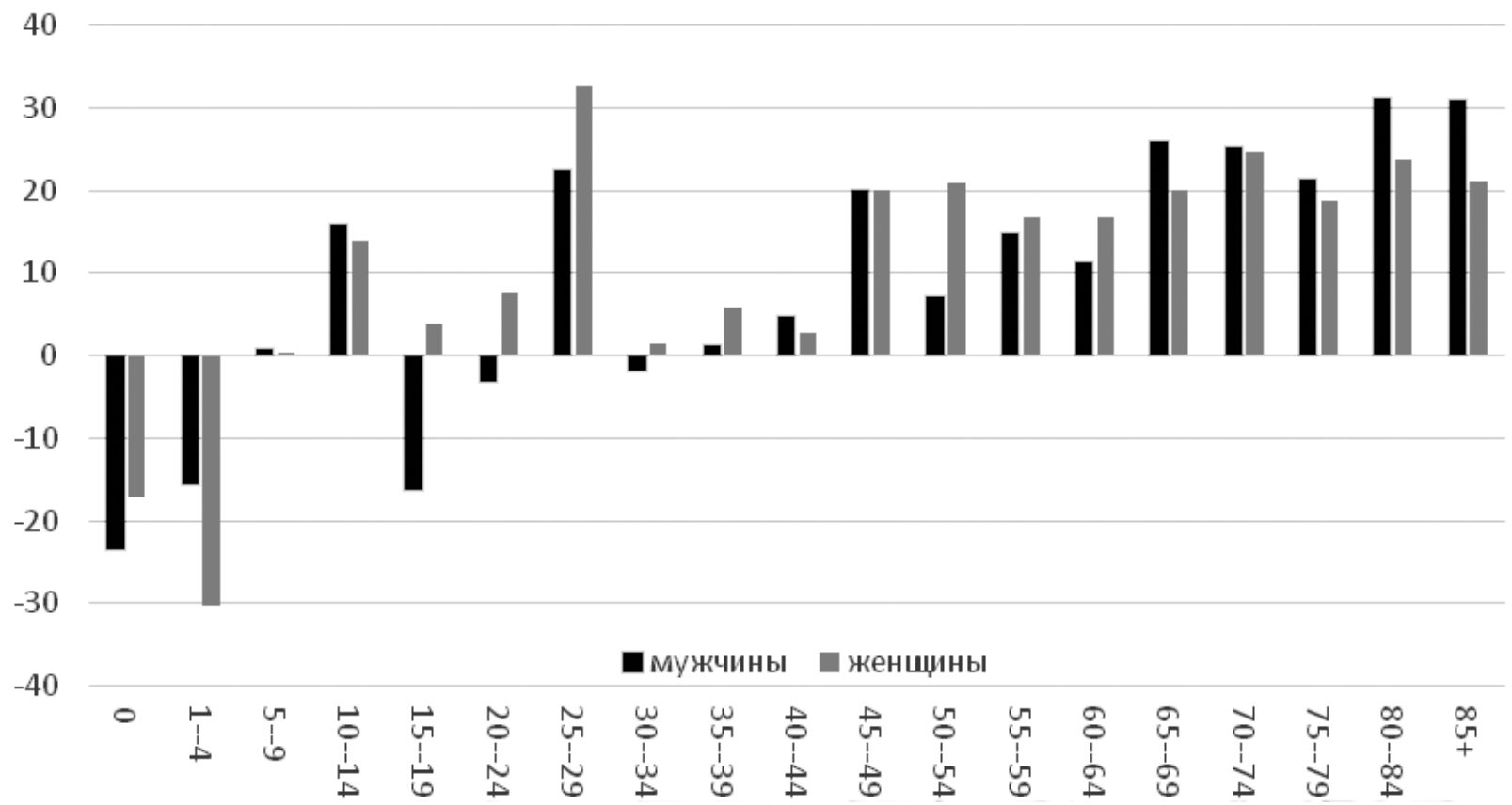

Рис. 1. Прирост (снижение) повозрастных показателей смертности в 2020 году в сравнении с 2019 годом, \% 
ния должна быть гораздо меньше, поэтому сравнение структуры смертности в периоды до и во время пандемии может оказаться информативным с этой точки зрения. Структура причин смерти по классам заболеваний является достаточно устойчивой в пределах кратковременного периода, а внутри отдельных классов под влиянием инфицирования SARSCOV-2 ведущими причинами смерти могут стать другие заболевания [2].

Изменение структуры причин смерти внутри класса инфекционных заболеваний очевидны: если в феврале (в марте уже наблюдались несколько смертей от COVID-19) доля болезней, вызванных ВИЧ (В20 по МКБ$10)$, составляла в инфекционной смертности $46,9 \%$ у мужчин и $56,5 \%$ у женщин, то во втором анализируемом периоде - лишь $4,5 \%$ и 3,6\% соответственно. Аналогично, доля хронических вирусных гепатитов (В18) снизилась с $23,3 \%$ у мужчин и $10,9 \%$ у женщин до 1,6\% и 1,3\%. Доля COVID-19 составляла соответственно 85,5 и 90,2\% в апреле и 93,3\% и $95 \%$ в мае 2020 года [2].

Рождаемость. Число родившихся в России в 2020 году составило 1435,7 тыс. человек, что на 48,8 тыс. или на 3,3 \% меньше, чем в 2019 году.
Основной вклад в снижение общих показателей рождаемости вносят изменения в половозрастной структуре населения в активный репродуктивный возраст входят малочисленные поколения родившихся в 1990-е годы (на начало 2020 года по сравнению с численностью 30-34-летних женщин, 25-29-летних было меньше более чем на четверть (на 26,7\%), а 20-24-летних - почти вдвое (на 46,1\%)).

Расчеты показывают, что за счет структурного фактора общий коэффициент рождаемости в России в 2020 году мог снизиться на 2,9\%. Фактическое его снижение (на $3 \%$ ) было почти таким же, и, вероятно (данных Росстата пока нет), суммарный коэффициент рождаемости остался практически на том же уровне, что в 2019 году - 1,5. Негативное влияние структурных сдвигов на динамику общих показателей рождаемости будет затухающим, но сохранится до 2029 года.

Динамика показателей рождаемости существенно различается по очередности рождения, имеет влияние структурного фактора. Благоприятная динамика численности женщин репродуктивного возраста имеет место в возрастах за 35 лет (число родившихся в России возрастало до 1987 года), в которых доля третьих и последующих рождений сущест-

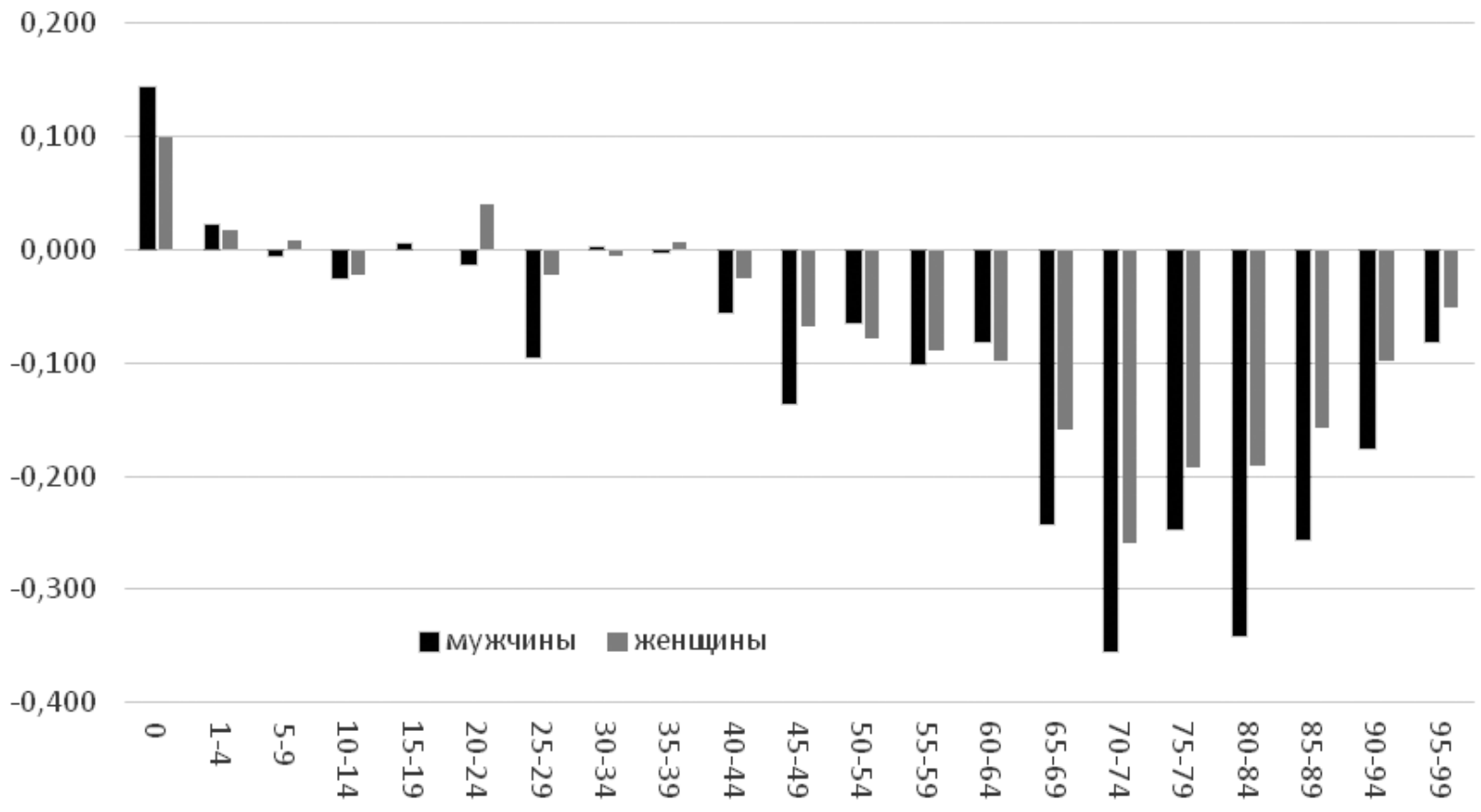

Рис. 2. Вклад возрастных групп в изменение продолжительности жизни населения в 2020 году в сравнении с 2019 годом, лет 
венно выше, чем у более молодых женщин. По предварительным оценкам, суммарный коэффициент рождаемости по первым рождениям в 2020 году составил 0,62 (2019-0,64), по вторым - 0,52 (2019 - 0,53), по третьим и последующим - 0,36 (2019-0,34). Таким образом, продолжилось снижение суммарного коэффициента рождаемости по первым и вторым рождениям (но в меньшей степени, чем в 2019 году) и повышение - по третьим и последующим рождениям.

В декабре 2020 года имел место значительный прирост числа зарегистрированных родившихся (впервые с 2016 года), по сравнению с декабрем 2019 года - на 9,0\%. Две гипотезы в отношении причины этого повышения:

- люди в конце года активизировались в регистрации рождений, имевших место в предыдущие месяцы;

- число родившихся возросло в связи с усилением мер помощи в начале 2000 года (прежде всего, материнский (семейный) капитал на первого ребенка).

Пока трудно сказать, что произошло, и оценить результативность материнского (семейного) капитала на первого ребенка (остальные меры помощи семьям с детьми, введенные в 2020 году, скорее, носили поддерживающий характер, а эта мера — характер отчасти стимулирующий).

В январе 2021 года число зарегистрированных родившихся значительно сократилось: на 10,3\% по сравнению с январем 2020 года и на $17,6 \%$ по сравнению с декабрем 2020 года.

Результативность дополнительных мер демографической политики в отношении рождаемости может быть связана либо с их большой значимостью, в т. ч. социальной (как это имело место при введении программы федерального материнского (семейного) капитала), либо с адресностью. Под адресностью в данном случае понимается не выделение семей по критерию уровня доходов, а учет условий жизнедеятельности, потребностей, репродуктивных намерений конкретных семей, т.е. оказание именно тех видов поддержки, в которых данная семья нуждается.

Одними из наиболее значимых мер поддержки семей с целью повышения рождаемости были бы, вероятно, меры содействия в улучшении жилищных условий. Представ- ляется, что они должны быть различными, чтобы семьи имели возможность получения поддержки при выборе того или иного способа улучшения жилищных условий. Жилищная проблема особенно актуальна для молодых семей, и ее решение могло бы способствовать повышению показателей рождаемости по первым рождениям, которые в России сейчас очень низкие, в т.ч., вероятно, в связи с откладыванием первых рождений.

При оказании помощи семьям с целью усиления ее адресности можно было бы шире использовать практику социального контракта, причем с учетом репродуктивного поведения семьи, т.е., например, социальным контрактом предусмотрено оказание той или иной помощи на определенный срок. В случае рождения ребенка помощь усиливается и продлевается.

В условиях ограниченных финансовых возможностей и априори неочевидного результата каких-либо дополнительных мер демографической политики целесообразно было бы перед внедрением в масштабах страны апробировать их в отдельных субъектах Российской Федерации для оценки результативности.

Миграция и миграционная политика. Согласно данным системы учета через отделения Министерства внутренних дел РФ в 2019 году было временно и постоянно зарегистрировано в России 19,5 тыс. иностранцев. Пандемия COVID-19 сократила их численность до 9,8 млн. человек в 2020 году. Главной проблемой современной системы статистического учета является отсутствие информации о численности конкретных людей, которые получили в течение каждого года временную регистрацию повторно, поэтому цифры регистрации весьма условно говорят о численности мигрантов, скорее, о количестве фактов регистрации, в том числе повторной.

В год пандемии COVID-19 количество выданных видов на жительство и российских паспортов гражданам Таджикистана увеличилось: в 2020 году 48,7 и 63,4 тыс. соответственно (в 2019 году было 29,6 и 44,7 тыс.). Сократилось только количество выданных разрешений на временное проживание: 31,4 тыс. в 2020 году и 46 тыс. в 2019 году соот- 
ветственно. Данная статистика является закономерной, поскольку общая миграция граждан Таджикистана в Россию сократилась, а РВП - первичный статус. Большинство иностранцев, которые с 2016 по 2020 годы получили российское гражданство, были гражданами Украины. Их доля среди получателей паспортов РФ составила 47\%, то есть 678,8 тыс. человек. На втором месте - граждане Казахстана (13\%), а на третьем - граждане Таджикистана (10\%). В 2020 году граждане Таджикистана (63,4 тыс.) были второй группой после граждан Украины (409,6 тыс.) среди получателей паспортов РФ, опередив выходцев из Казахстана.

В России увеличивается дефицит рабочей силы. Если в 2018 году численность рабочей силы в России была 76,2 млн. человек, то в прошлом году - уже 75,4 млн., а за пять месяцев 2020 года — 74,7 млн. человек. Во время пандемии COVID-19 дефицит рабочей силы в России усилился из-за сокращения притока трудовых мигрантов и составил по экспертным оценкам в начале 2021 года около 1 млн. человек. Наиболее остро нехватка трудовых ресурсов ощущается в строительстве, торговле, некоторых отраслях промышленности, сельском хозяйстве в Краснодарском крае, Московской области, Москве, Санкт-Петербурге, Тюменской, Астраханской и Свердловской областях.

В настоящее время между Россией и странами Центральной Азии отрабатываются механизмы организованного набора рабочей силы. В условиях коронавирусных ограничений фактически активизировался процесс формирования механизма организованной трудовой миграции, о котором говорилось достаточно давно до пандемии COVID-19 как об идеальной модели миграционных отношений. Ведется работа с Узбекистаном и Таджикистаном.

В 2018 году утверждается новая Концепция государственной миграционной политики на период 2019-2025 года. В ней иммиграция определяется в качестве дополнительного источника (после «естественного воспроизводства») восполнения населения Российской Федерации и обеспечения национальной экономики трудовыми ресурсами. А миграционная политика называется «вспомогательным средством для решения демографических проблем и связанных с ними экономических проблем. Она должна быть направлена на создание благоприятного режима для добровольного переселения в Россию лиц, которые способны органично включиться в систему позитивных социальных связей и стать полноправными членами российского общества».

Также с 2007 года в России стартовала Государственная программа по оказанию содействия добровольному переселению в Россию соотечественников, проживающих за рубежом (Указ Президента РФ от 22 июня 2006 года) [2]. В 2012 году программа стала бессрочной. Фактически программа, которая задумывалась как репатриационная по возвращению русскоговорящего населения, превратилась в программу организованного привлечения трудовых ресурсов с элементами этнополитики, поскольку участие в ней тесно связано с возможностью трудоустройства в конкретном регионе России. При переселении участники программы получают различные выплаты и компенсации, российское гражданство в упрощенном порядке. По данным Главного управления по вопросам миграции МВД России, за 2007-2020 годы действия программы в Россию вернулись около 960 тыс. человек $[4,5]$. В 2020 году в Россию прибыли 62,9 тыс. соотечественников, что из-за пандемии COVID-19 было меньше, чем в 2019 году — 108,5 тыс. человек. Значительная часть участников Государственной программы (83\%) приходилась в 2020 году на граждан стран Центральной Азии, в том числе Казахстана (37,6\%), Таджикистана (34,6\%), Узбекистана (5,2\%), Кыргызстана (4,3\%), Туркменистана (1,3\%) [6].

Стратегические меры, необходимые для преодоления новой (второй) волны депопуляции в России. Совершенно очевидно, что вторая волна депопуляции требует разработки новых мер демографической и миграционной политики, которые помогут компенсировать сокращение численности населения в России. Для выхода из второй волны депопуляции требуется научно-обоснованная национальная демографическая программа, в которой целесообразно выделить четыре направления мер.

Во-первых, требуется продолжить улучшать условия для рождения и воспитания де- 
тей, поддерживать материально и социально семьи с детьми, в том числе многодетные, и молодых супругов, что поможет реализовать репродуктивные установки вовремя и не приведет к их откладыванию.

Во-вторых, меры по развитию самосохранительного поведения, сокращению смертности от внешних причин, в том числе пандемий, аналогичных COVID-19, что будет способствовать сокращению смертности и увеличению продолжительности жизни, а в конечном итоге обеспечит естественный прирост населения.

В-третьих, создание условий для самореализации населения внутри страны, ориентированного на эмиграцию из России, что также обеспечит миграционный прирост населения. В настоящее время значительное количество молодых и трудоспособных людей эмигрировало на постоянное место жительство или живет между двумя странами. Эмиграция, к сожалению, вымывает трудовой, репродуктивный, интеллектуальный, квалификационный и предпринимательский потенциал страны.

В-четвертых, требуется привлечение мигрантов различных категорий, которые хотят жить и работать в России, чтобы обеспечить миграционный прирост населения. В современных условиях следует усиливать вклад миграции русского и русскоговорящего населения, которое еще ориентировано на Россию. Пока еще возможно увеличить возвращение соотечественников из стран бывшего СССР, где проживает до 14 млн. человек. Из них до 4 млн. человек могут быть реальным возвратным миграционным потенциалом [1]. К сожалению, пока миграционные сервисы не всегда работают эффективно. Многие соотечественники сталкиваются со сложностями при регистрации по месту пребывания и месту жительства, процедуры получения вида на жительства и гражданства забюрократизированы. Требует реформирования один из главных источников появления недокументированных мигрантов в России - жесткие и неразумные правила регистрации по месту пребывания. Регистрация должна стать уведомительной и отражать реальное место пребывания и жительства человека и не быть препятствием на пути его легализации. В настоящее время многие миг- ранты не могут зарегистрироваться по реальному месту проживания из-за нежелания собственников жилья.

В 2019 году Президентом РФ В.В. Путиным была инициирована новая волна действий по реформированию миграционного режима и института гражданства в России в сторону упрощения процедур для соотечественников. В документах отмечается, что «точечные изменения миграционного законодательства, а равно ужесточение юридической ответственности не приведут к качественному улучшению состояния миграционной сферы» [6, 7]. Мигранты рассматриваются как человеческий капитал, демографические, интеллектуальные и трудовые ресурсы для страны. А усилия российского государства в области миграционной политики должны быть направлены на то, чтобы снять препятствия и барьеры на пути оформления правого статуса людям, которые рассматривают переезд в Россию на постоянное место жительство. Ликвидируется разрешение на временное проживание как лишняя ступень в системе миграционных статусов. Открывается канал перехода в российское гражданство для трудовых мигрантов, большинство из которых в России происходит из стран бывшего CCCP.

В настоящее время перед демографическими исследованиями стоят задачи выявить причины и особенности второй волны депопуляции в России, определить ее возможные социально-демографические и геополитические последствия, выделить резервы для компенсации убыли населения страны и отдельных регионов России, определить возможные резервы компенсации потерь населения за счет миграционных процессов.

\section{Литература}

1. Демографическая ситуация в России: новые вызовы и пути оптимизации: национальный демографический доклад [Электронный ресурс]/ Под ред. чл.-корр. РАН, д.э. н. С. В. Рязанцева - М.: Изд-во «Экон-Информ», 2019. - 79 с. - Режим доступа: http:// испи.pф/wp-content/uploads/2019/06/Нацдоклад23мая2019итог.pdf.

2. Сабгайда Т.П., Иванова А.Е., Руднев С.Г., Семенова В.Г. Причины смерти 
москвичей до и в период пандемии COVID-19 [Электронный ресурс] // Социальные аспекты здоровья населения. - 2020. - №4(66). Режим доступа: http://vestnik.mednet.ru/ content/view/1177/30/lang, ru/.

3. Указ Президента РФ от 14.09.2012 г. №1289 (ред. от 24.07.2020 г.) «О реализации Государственной программы по оказанию содействия добровольному переселению в Российскую Федерацию соотечественников, проживающих за рубежом» [Электронный ресурс]. - Режим доступа: http://www. consultant.ru/document/cons doc LAW 135 348/9cf95e 1 cef34d74eca9a5 $\overline{79} 26 \overline{7} 1 \mathrm{e} 8 \mathrm{c} 9 \overline{\mathrm{e}} 40 \mathrm{~d}$ b0c $88 /$.

4. Почти 1 млн. человек переехали в РФ по программе переселения за 13 лет [Электронный ресурс] // INTERFAX.RU. — Режим доступа: https://www.interfax.ru/russia/731533 (Дата обращения: 14.10.2020).

5. Основные показатели по миграционной ситуации в Российской Федерации за январьдекабрь 2019 года [Электронный ресурс]. Режим доступа: https://мвд.pф/Deljatelnost/ statistics/migracionnaya/item/19364859/ (Дата обращения: 22.01.2020).

6. Мониторинг реализации Государственной программы по оказанию содействия добровольному переселению в Российскую Федерацию соотечественников, проживающих за рубежом, на территориях вселения субъектов Российской Федерации в IV квартале 2020 года [Электронный ресурс] // Министерство внутренних дел Российской Федерации. - Режим доступа: https:/Мвд. $\mathrm{p} \phi / \mathrm{mvd} /$ structure1/Glavnie_upravlenija/guvm/ compatriots/monitoring/2020.

7. Перечень поручений по вопросам реализации Концепции государственной миграционной политики на 2019-2025 годы [Электронный ресурс] // Президент России. Официальный сайт. - Режим доступа: http:// www.kremlin.ru/acts/assignments/orders/62960 (Дата обращения: 06.03.2020).

8. Распоряжение Президента РФ «О рабочей группе по реализации Концепции государственной миграционной политики Российской Федерации на 2019-2025 годы» №58-p от 06.03.2019 г. [Электронный ресурс]. - Режим доступа: http://pravo.gov.ru/ proxy/ips/?docbody $=\&$ prevDoc $=102603009 \& b$ acklink $=1 \& \&$ nd $=102525921$.

\section{References}

1. Demograficheskaja situacija v Rossii: novye vyzovy i puti optimizacii: nacional'nyı̆ demograficheskiū doklad [Demographic situation in Russia: New challenges and ways of optimization: national demographic report] [Jelektronnyj resurs] / In chl.-korr. RAN, d. je. n. S.V. Rjazancev (eds.) - Moscow: Izd-vo «Jekon-Inform», 2019. - 79 p. — URL: http:// ispi.rf/wp-content/uploads/2019/06/Nacdoklad23maja2019itog.pdf.

2. Sabgajda T.P., IvanovaA.E., RudnevS.G., Semenova V.G. Prichiny smerti moskvichej do i v period pandemii COVID-19 [Causes of death of Muscovites before and during the COVID-19 pandemic] [Jelektronnyj resurs] // Social'nye aspekty zdorov'ja naselenija [Social aspects of population health]. 2020. — №4(66). — URL: http://vestnik.mednet.ru/content/view/1177/30/lang, ru/.

3. Ukaz Prezidenta RF ot 14.09.2012 g. №1289 (red. ot 24.07.2020 g.) «O realizacii Gosudarstvennoj programmy po okazaniju sodejstvija dobrovol'nomu pereseleniju v Rossijskuju Federaciju sootechestvennikov, prozhivajushhih za rubezhom» [Decree of the President of the Russian Federation of 14.09.2012 №1289 (ed. of 24.07.2020) «On the implementation of the State Program to assist voluntary resettlement to the Russian Federation of compatriots living abroad»] [Jelektronnyj resurs]. — URL: http:// www.consultant.ru/document/cons_doc_LAW 135348/9cf95e1 cef34d74eca9a579267 $\overline{1}$ e8c9e $\overline{4}$ $0 \mathrm{db} 0 \mathrm{c} 88 /$.

4. Pochti $1 \mathrm{mln}$. chelovek pereehali v RF po programme pereselenija za 13 let [Almost 1 million people moved to the Russian Federation under the resettlement program for 13 years] [Jelektronnyj resurs] // INTERFAX.RU. - URL: https://www.interfax.ru/russia/731533 (Date accessed: 14.10.2020).

5. Osnovnye pokazateli po migracionnoj situacii v Rossijskoj Federacii za janvar'-dekabr' 2019 goda [Key indicators on the migration situation in the Russian Federation for January-December 2019 [Jelektronnyj resurs]. URL: https://mvd.rf/Deljatelnost/statistics/migracionnaya/item/19364859/ (Date accessed: 22.01.2020).

6. Monitoring realizacii Gosudarstvennoj programmy po okazaniju sodejstvija 
dobrovol'nomu pereseleniju v Rossijskuju Federaciju sootechestvennikov, prozhivajushhih za rubezhom, na territorijah vselenija sub\#ektov Rossijskoj Federacii v IV kvartale 2020 goda [Monitoring the implementation of the State Program for Assistance to voluntary resettlement in the Russian Federation of compatriots living abroad in the territories of settlement of the subjects of the Russian Federation in the IV quarter of 2020] [Jelektronnyj resurs] // Ministerstvo vnutrennih del Rossijskoj Federacii [Ministry of Internal Affairs of the Russian Federation]. URL: https://mvd.rf/mvd/structure1/Glavnie upravlenija/guvm/compatriots/monitoring/2020.

7. Perechen' poruchenij po voprosam realizacii Koncepcii gosudarstvennoj migracionnoj politiki na 2019-2025 gody [List of instructions on the implementation of the Concept of State migration policy for 2019-2025] [Jelektronnyj resurs] // Prezident Rossii. Oficial'nyj sajt [President of Russia. Official website]. — URL: http:// www.kremlin.ru/acts/assignments/orders/62960 (Date accessed: 06.03.2020).

8. Rasporjazhenie Prezidenta $\mathrm{RF} « \mathrm{O}$ rabochej gruppe po realizacii Koncepcii gosudarstvennoj migracionnoj politiki Rossijskoj Federacii na 2019-2025 gody» №58-r ot 06.03.2019 g. [Decree of the President of the Russian Federation «On the Working Group on the implementation of the Concept of the State Migration Policy of the Russian Federation for 2019-2025» №58-r of 06.03.2019] [Jelektronnyj resurs]. — URL: http://pravo.gov.ru/proxy/ ips/?docbody $=\&$ prevDoc $=102603009 \&$ backlin $\mathrm{k}=1 \& \& \mathrm{nd}=102525921$.

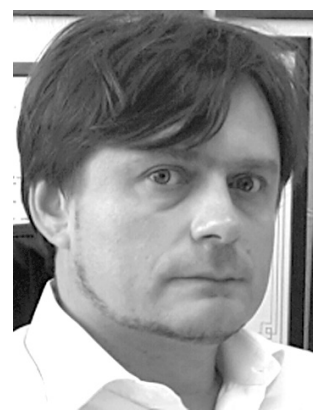

Рязанцев Сергей Васильевич - член-корресподент РАН, директор Института демографических исследований Федерального научно-исследовательского социологического центра РАН, заведующий кафедрой демографической и миграционной политики МГИМО МИД России.

Ryazantsev Sergey Vasilievich - Corresponding Member of the Russian Academy of Sciences, Director of the Institute of Demographic Research of the Federal Research Sociological Center of the Russian Academy of Sciences, Head of the Department of Demographic and Migration Policy, Moscow State Institute of International Relations of the Ministry of Foreign Affairs of Russia.

119333, г. Москва, ул. Фотиевой, 6, корп. 1

6 Fotievoj str., bld. 1, 119333, Moscow, Russia

E-mail: riazan@mail.ru 

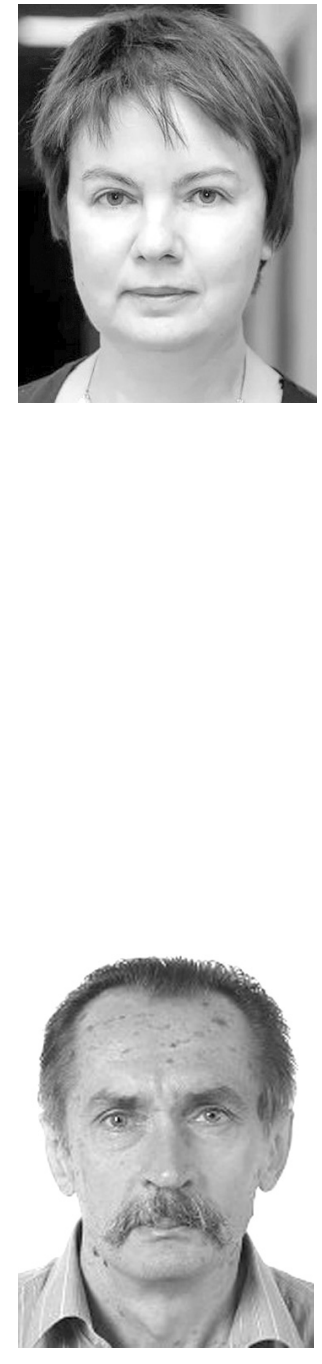

Иванова Алла Ефимовна - доктор экономических наук, профессор, главный научный сотрудник Института демографических исследований Федерального научно-исследовательского социологического центра РАН.

Ivanova Alla Efimovna - Doctor of Economic Sciences, Professor, Chief Researcher of the Institute of Demographic Research of the Federal Research Sociological Center of the Russian Academy of Sciences.

119333, г. Москва, ул. Фотиевой, 6, корп. 1 6 Fotievoj str., bld. 1, 119333, Moscow, Russia

E-mail: ivanova-home@yandex.ru

Архангельский Владимир Николаевич - кандидат экономических наук, ведущий научный сотрудник Института демографических исследований Федерального научно-исследовательского социологического центра РАН.

Arkhangelsky Vladimir Nikolaevich - Candidate of Economic Sciences, Leading Researcher of the Institute of Demographic Research of the Federal Research Sociological Center of the Russian Academy of Sciences.

119333, г. Москва, ул. Фотиевой, 6, корп. 1

6 Fotievoj str., bld. 1, 119333, Moscow, Russia

E-mail: archangelsky@yandex.ru 